\title{
COUNTRY OF ORIGIN, COVID-19 VACCINE AND THE FUTURE OF TRAVEL: A PRELIMINARY STUDY IN IRAN
}

\author{
Sara Mirzaee ${ }^{*}$, Reyhaneh Jalalinejad ${ }^{\star \star} \&$ Babu George ${ }^{* \star *}$
}

\begin{abstract}
Country-of-origin is one of the most crucial aspects of a brand's success. Country-of-origin has a significant impact on how brands are perceived, especially in terms of the promise of quality they deliver. While different countries have announced vaccines, there has been a global hesitation to buy into those claims. Successful adoption of a successful vaccine is critical to re-launching global travel and the leisure economy. In this article, we discuss the importance of country of origin in products getting the trust needed for them to succeed - particularly a vaccine for Covid-19. A preliminary survey was conducted among 662 Iranian social media users, directly on Linkedln and also via a Google survey instrument. Germany merged to be the iconic symbol of quality and transparency and respondents felt confident that they would not hesitate to be subjected to a German made vaccine. Germany is globally perceived as a quality leader in high technologies and medicine and Iranians concurred with this belief.
\end{abstract}

Keywords: Country of origin; Branding; Vaccine; Covid-19; Tourism; Iran.

\section{PAÍS DE ORIGEM, VACINA COVID-19 E O FUTURO DAS VIAGENS: UM ESTUDO PRELIMINAR NO IRÃ}

\begin{abstract}
O país de origem é um dos aspectos mais cruciais para o sucesso de uma marca. O país de origem tem um impacto significativo na forma como as marcas são percebidas, especialmente em termos da promessa de qualidade que elas oferecem. Embora diferentes países tenham anunciado vacinas, tem havido uma hesitação global para comprar essas reivindicações. A adoção bem-sucedida de uma vacina bem-sucedida é fundamental para relançar as viagens globais e a economia do lazer. Neste artigo, discutimos a importância de o país de origem dos produtos obter a confiança necessária para o seu sucesso - particularmente uma vacina para o Covid-19. Foi realizada uma pesquisa preliminar entre 662 usuários da mídia social iraniana, diretamente no Linkedln e também através de um instrumento de pesquisa do Google. A Alemanha fundiu-se para ser o símbolo icônico de qualidade e transparência e os entrevistados se sentiram confiantes de que não hesitariam em ser submetidos a uma vacina de fabricação alemã. A Alemanha é vista globalmente como líder de qualidade em altas tecnologias e medicina e os iranianos concordaram com esta crença.
\end{abstract}

Palavras-chave: País de origem; Marca; Vacina; Covid-19; Turismo; Irã.

\section{PAÍS DE ORIGEN, VACUNA COVID-19 Y EL FUTURO DE LOS VIAJES: UN ESTUDIO PRELIMINAR EN IRÁN}

El país de origen es uno de los aspectos más cruciales para el éxito de una marca. El país de origen tiene un impacto significativo en cómo se perciben las marcas, especialmente en términos de la promesa de calidad que ofrecen. Mientras que diferentes países han anunciado vacunas, ha habido una vacilación global para comprar esas afirmaciones. El éxito de la adopción de una vacuna es fundamental para relanzar los viajes y la economía del ocio a nivel mundial. En este artículo se analiza la importancia del país de origen para que los productos obtengan la confianza necesaria para su éxito, en particular una vacuna contra el Covid19. Se realizó una encuesta preliminar entre 662 usuarios de medios sociales iraníes, directamente en Linkedln y también a través de un instrumento de encuesta de Google. Alemania se fusionó para ser el símbolo icónico de la calidad y la transparencia y los encuestados se sintieron seguros de que no dudarían en someterse a una vacuna fabricada en Alemania. Alemania es percibida globalmente como un líder de calidad en altas tecnologías y medicina y los iraníes coincidieron con esta creencia.

Palabras clave: País de origen; Marca; Vacuna; Covid-19; Turismo; Irán.

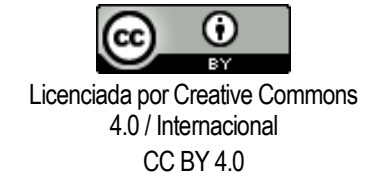

* DBA / SMCU (2014), is an internationally renowned business consultant and coach based in Iran. She is also a visiting professor at several universities. Her primary research interest is in understanding subliminal layers of consumer choice. Her doctoral research examined the role of archetypes in buyer behavior. She has authored more than ten books on various dimensions of marketing and business management. CV: https://orcid.org/0000-0001-5928-6072 [ saramirzaee@hotmail.com ]

${ }^{*}$ MBA / UT, is an FMCG marketing professional. As a consultant, she serves multiple industry vertices. She has got specific expertise in product development and management in the FMCG industry. CV: https://orcid.org/0000-0003-0974-2425 [ Reyhane.jalalinejad@gmail.com ]

*** PhD / GU (2006), DBA / SMCU (2016), EdS / FHSU (2019), is Professor of International Business and Associate Dean in the School of Business of Christian Brothers University, USA. More recently, he has studied extensively the crisis management challenges during Covid-19 and has published several books and monographs on this topic. CV: https://orcid.org/0000-00022791-828X [bgeorge@cbu.edu ] 


\section{INTRODUCTION}

In recent years, in a highly globalized world and a super competitive business environment, international firms are looking for more global market opportunities (Abdin \& Kumar, 2020, George, Li, \& Hou, 2020). While the tourism industry evinced the triumph of the global market over the territories of national economies, no less true is that globalization paved the ways for the expansion of capital-owners and investors worldwide (Korstanje, 2020). Tourists and businessmen move to look new opportunities. While the former is in quest of novel experiences, the latter looks for new profits (Javier, Valdez \& Mendoza, 2020).

Having said this, many factors affect the evaluation of consumer products and services, such as brand, color, and design; yet, researchers cannot ignore extrinsic factors like the country of origin (Kolbl, Arslanagic-Kalajdzic, \& Diamantopoulos, 2019).

Studies show that country of origin is one of the factors that most concern marketers regarding its impact on consumer purchase intention (Lin \& Chen, 2006; Purnell, 2002). Country-of-origin is a variable for determining the quality of products.

Country-of-origin has a significant impact not just on how brands are perceived but also on personnel brands: Magier-Lakomy and Rozkwitalska (2013) highlights how the country of birth influences how others' see someone's competence. Even though the country-of-origin effect is irrational in many contexts, this cannot be neglected due to its impact on perceptions (Parkinson, 2009).

Discussions on rebooting tourism and travel in the post-Covid world cannot underestimate this dynamic. It is not only important that there should be vaccine but also that the said vaccine be adopted by people around the world. While this research note is being typeset, there is a Russian vaccine that is making its rounds; yet, there is widespread suspicion and cynicism about the effectiveness of it.

Also, people are concerned about the adverse side effects of taking them. Thus, directly or indirectly, the country of origin of a vaccine has got important implications for international tourism and global trade in general.

\section{BACKGROUND}

Branding is a technical, critical, and timeconsuming issue, and anyone, anything, or country can be branded (Almeyda-lbáñez, \& George, 2017; Henthorne, George, \& Miller, 2016).

There have been a few in-depth studies of branding and destination image related to Iran (Haghighi, Gharleghi, \& Nikbakht, 2012; Jalilvand,
Esfahani, \& Samiei, 2010; Khodadadi, 2019); yet, most of them focused on the recreational aspects of place branding and did not connect the country image with the trust of products (Shahin, Kazemi, \& Mahyari, 2012).

In a certain way, the trust of Iranian brands may be greater among the Iranian diaspora overseas than those living in Iran (Bozorgmehr, 1997). Similar patterns were observed by Henthorne, Williams, and George (2018), as well. Unfortunately, in the past years, Iran's brand image in the world has been destroyed, although no single organization is responsible for this crucial issue.

Branding is not new to Iran. In fact, in medieval times or even before, products originated in Iran commanded a premium price (Mirazee \& George, 2016). Brands simplify abstract ideas and embody them into easily understandable terms (Keller \& Lehmann, 2006).

However, such leadership was lost, fast forward to late 1900 s. Since then, it sounded as though it was unbelievable for Iranians that there were opportunities for branding certain products. People went to a bakery to buy local bread or used Tehran local water, just like indistinguishable commodities.

Entrepreneurs, though late, saw that even water and bread were branded. However, Iranian leadership in quality manufacturing or service did not come back to the earlier days of glory. Thinking of branding in broader terms, not just products and services can be branded but also cities and whole countries (Papadopoulos \& Heslop, 2002). Brands for places are often an aspect of their internationalization and global recognition (Tantawy \& George, 2016).

As soon as the name Switzerland comes to our minds, quality, Cleanliness, prestige, quality watches, Chocolate, good coffee, and the best banks in the world come to mind. While no coffee is produced in Switzerland, but in this category, the product is branded, and Switzerland and the Netherlands, despite their small size and population, have become two good countries in the field of dairy. The importance of the country of origin in branding has increased in recent years.

Perhaps in the last 40 years, electrical appliances were only European brands, and Japan 40-50 years ago was like China today. At that time, people's first choice was European brands, but Japan made great efforts to grow and strengthen the world's Japanese brand during these years.

Like Sony, it set its vision on upgrading Japan's image as high quality in the world. To the Sony brand 40 years ago, and that is what happened, and now a brand like Lexus Toyota is competing with powerful German brands like Benz and BMW. 
Various industries realized the importance of branding and became a leader in quality in almost many Japanese industries, for example, in the field of cosmetics, it introduced one of the most expensive and high-quality cosmetic brands called "Shiseido" to the world, and probably one of the most prominent and most expensive brands in the world.

Precisely following Japan's example, South Korea globalized its brands, and we see how strongly LG and Samsung, or Hyundai and Kia, penetrated the world. Top brands have different approaches, and of course, the value of each brand is different. The evidence exists to show that global and high-value brands, which are the top 100 globally, are often from North America and Europe.

Highly effective brands have sufficient investment, sound business models, brave accounting practices, and quality products and services (Holt, 2002). They are not in competition over quality and pricing, but they become successful. However, those who want to succeed by pricing but not developing brands do not become successful in obtaining their desired results.

The problem arises because these firms often neglect the importance of attracting and engaging their workforce and customers that will push them to the edge, and it appears that quality costumers and workforce are pulled away from by bigger and betterknown brands (Okonkwo, 2016). No one can operate in a complete silo, and no one can genuinely operate without outside help. This concept can also be applied to brands (Fan, 2005). This asset can create valuable novel products and services.

In reality, most businesses are founded on their workforce's foundation, yet this particular competitive advantage is not invested in properly. For a brand to succeed, it has to deliver a particular salience to and communicate well with its stakeholders, and one of the most important stakeholders of a company is its workforce (Schroeder, 2009).

Companies in our sphere do not set their brands' foundation on knowledge and insights, purpose and vision, or customers' proper understanding (Holt \& Holt, 2004). They focus on the quality of the process and products, but they do not focus on employing and training their most precious asset: their workforce. If continued, this approach will fail (Abimbola, Lim, Oster, Punjaisri, Cheng, 2010).

For the next insight, focusing on one top brand's successful practices and point to one simple but immediately powerful difference of approach in Research \& Development. How is it that companies such as Apple keep continuing to win their consumers' hearts and minds worldwide, yet they continue to push to introduce new and innovative ideas?
The strategic thinking behind companies like Apple is different from Asian brands in that they produce original ideas, not merely taking the easy way of benchmarking and imitating established products and models.

According to Catherine Chai (2016), Xiaomi, one of the top electronic companies in China ("Xiaomi," meaning Affordable Technology), is a great case study. Xiaomi is the owner of shops, but by using its main communication channels, it has cleverly succeeded in penetrating social media to advertise new products and personalize its smartphones to attract massive demand ultimately.

In contrast with Apple that keeps its products' development process secret, Xiaomi has more than 16 million customers who continually contribute their feedback towards the betterment of the products, features, and services. Xiaomi is a huge advocate of "Co-Creation," a concept referring to the collaborative process taken through collaboration with a select group of users to co-produce a product together with designers. Xiaomi believes that contrary to other smartphone brands that take six months or even more to design and release new versions, Xiaomi can release new bundles of products weekly.

Based on the motto "Made by Your Design," Chief Product Officer contributes some of his time for gathering user feedback on Customer Forums, and every time, it picks a new recommendation to be ideated and designed by one of their Research and Development engineers in a matter of hours. Recommended feedback can develop into a new feature or product in a matter of a week, and its finer soft or hardware details can be modulated with the help of further focused feedback.

From technology to globalization, such a method is something that, in some companies faster, and in others, it has taken longer to instill (Chai, 2016). Although China has overwhelmed global markets, the general belief in Chinese goods is of low quality. Brands such as Huawei and Xiaomi, which have tried hard for years but have not yet been able to achieve a position like Apple or Samsung, it is true that any brand can Target a specific segment of the market, but indeed if Huawei or Xiaomi were in markets like Japan and Korea or Europe and the US, they would have different brand power.

In summary, what influences the branding of the country of origin is a set of factors, for example, the policies of the leaders of that country, the degree of honesty and transparency, the way their country is governed, and the well-being of the people and all have an impact on creating a strong mental image of the country (Papadopoulos, N., \& Heslop, 2002). 


\section{THE STUDY}

We face a worldwide crisis, and life will never be the same after the novel virus, Coronavirus 2019 (COVID-19). Most people understand that battling this virus is a biological war but is based on political and economic reasons.

Several countries are working on related vaccines, while the question remains about whom to trust for a vaccine. Again, the importance of country of origin has an impact on people's choices.

A survey on Linkedln and also through google survey were run by us during early 2020 to query different people's point of view regarding their trust to the country of origin of different countries and what is their first choice precisely after Russia claimed having developed a Covid-19 vaccine was done.

In addition, the researchers spoke with many industry leaders from different Asian brands about how it is that even though there are so many brands and tight competition, we cannot produce top global brands in many Asian countries.

The total number of participants in the study was 304 people through google survey and 358 in Linkedln; $69 \%$ were males and $31 \%$ were females. The levels of education of the participants were as follows: doctorates (49\%); masters (26\%); bachelors $(13 \%)$; diploma/certificate program holders (12\%). The sample was composed of well-educated individuals.

\section{FINDINGS}

The following two pie charts summarize the findings from the Google survey and the Linkedln survey conducted with the objective of figuring out individuals' preferences for vaccines as a function of country of origin (See Figures $1 \& 2$ ).

As the chart shows, Germany was the first choice with the highest score, in both surveys. Why? Because it has always been honest and provided quality goods, such as high-quality cars and other products.

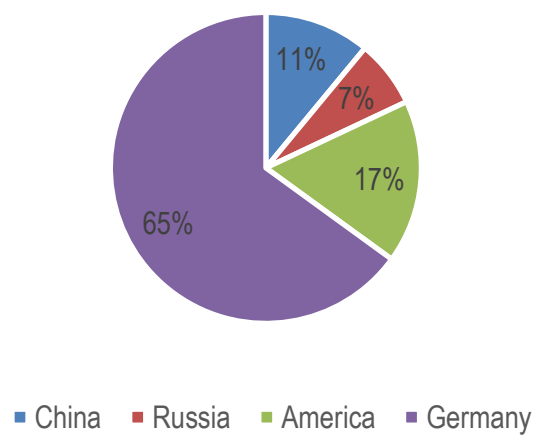

Figure 1: Which country's vaccine will be your first choice? Source: Google Survey Findings.

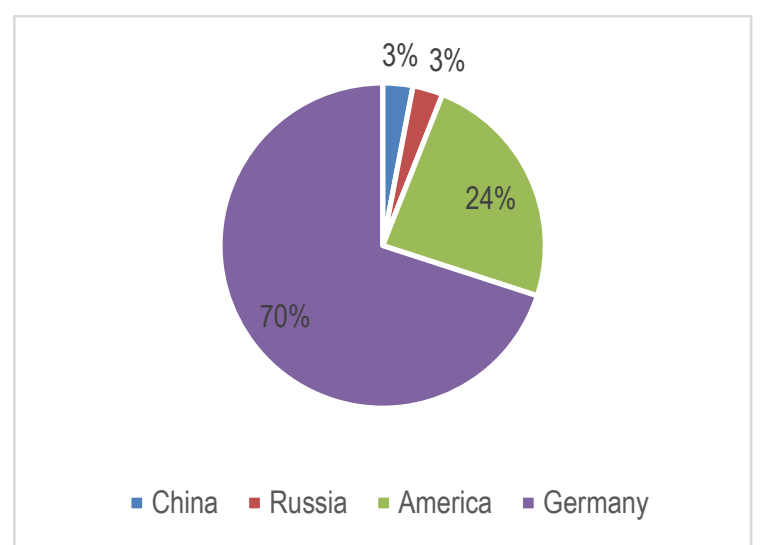

Figure 2: Which country's vaccine will be your first choice? Source: Google Survey Findings.

Even in the pharmaceutical industry, one of the largest groups worldwide, "Merck," is German, and it is one of the most famous and best companies in the world. Russia known for its lack of transparency and conservatism failed to score high in this survey. China did not score well, either.

Despite having a few large and strong pharmaceutical companies, the United States did not have a good position compared to German, and indeed, President Trump's policy has had a significant impact on the United States' position over the past four years.

It is exigent to mention that every country can build a strong position in a particular field. For example, the United States in technology has been able to prove its power and superiority in the world.

The United States is the center of the world's talents. Silicon Valley is full of the world's talents. However, a country like Switzerland has always been able to grow significantly in the various commodities mentioned earlier, even the pharmaceutical industry.

Unfortunately, in the Iranian government's plans, the importance of branding has never been taken seriously. Iran could brand itself in carpets, saffron, and pistachios in the world, but due to lack of attention and lack of teamwork culture and long-term vision in brand building.

This privilege is now available to other countries, and countries like Spain, which repackages Iranian saffron with their brands, are more potent in this field. Alternatively, in carpets, China, India, and Pakistan have grown so much that they have taken Iran's share in world markets.

\section{CONCLUSIONS}

This preliminary research indicates that Iranian consumers have notions of quality for vaccines associated with the countries of origin of those 
vaccines. This is not unexpected. There are numerous pharmaceutical companies around the world invested in developing vaccines now.

This research does not address when a vaccine will be widely available but rather identify the consumer preferences in a part of the world that is known to have distinct tastes. This is a unique sample and the notions held by it are important. A chain cannot be stronger than its weakest link; immunity weak spots anywhere in the world would be inviting further waves of global chaos (George \& Bucatariu, 2020).

There is a silver lining, however: the more the time it takes for a country like Germany to develop a vaccine, the greater the chance for malignant effects from tourism to reverse. Global warming is just one of these effects (Korstanje, \& George, 2012).

Also, weeks and months that people stay locked won inside closeted spaces may make them recognize the value of clean and sustainable outdoors. Covid-19, thus, might help create a better version of tourism, whenever things go back to normal. Hall, Scott, and Gossling (2020) however, also warns of the likely resurgence of tourism policies reflecting the selfish nationalism of some countries, in the guise of managing the pandemic.

There is an old saying that says, "keep your friends close and keep your enemies closer." To excel in business, considering the competition is necessary. Knowing your rivals' strengths will help you identify the weaknesses of your performance and avoid your opponent's trap and simulate their success (Dubey \& George, 2012).

Today's successful companies and brands must adapt to rapid changes, which means continuous monitoring of the market and how social, technological, legal and economic developments unfold. Stay tuned to modern practices, and cultivating an inner culture is paramount in brands' success from the developing world because, without them, they will fall into mediocracy.

Due to high competition and the speed of changes and, more importantly, the consumer's higher expectations, the importance of branding becomes more and more and the stronger the country of origin, the more successful brands under the umbrella of their country. In the next months, we will see how Covid-19 Vaccine reveals in the market, and possibly reinforce the current lines of divide.

People in countries like Iran which have been at the receiving ends of sanction may continue to suffer by not getting effective vaccines. The global tourism economy would not care too much either, because, again due to sanctions, there is very little to gain directly from Iranians getting vaccinated. In other words, the patterns of global travel post-Covid will also be a function on where, when, and how an effective vaccine reaches.

\section{REFERENCES}

Abdin, M. S., \& Kumar, R. (2020). Economic Impact of Novel Corona Virus Disease (Covid-19) on Migrant Workers, Rural Economy of India and Tourism. Revista Anais Brasileiros de Estudos Turísticos-ABET (ISSN 22382925), 10(1, 2 e 3).

Abimbola, T., Lim, M., Foster, C., Punjaisri, K., \& Cheng, R. (2010). Exploring the relationship between corporate, internal and employer branding. Journal of Product \& Brand Management, 13, 16-22.

Almeyda-lbáñez, M., \& George, B. P. (2017). The evolution of destination branding: A review of branding literature in tourism. Journal of Tourism, Heritage \& Services Marketing, 3(1), 9-17.

Bozorgmehr, M. (1997). Internal Ethnicity: Iranians in Los Angeles. Sociological Perspectives, 40(3), 387-408.

Chai, C. (2016). From Bland to Brand, The Essential Branding Handbook for Asian Businesses. Rethink Press.

Dubey, J., \& George, B. P. (2012). Rebranding@ Airtel: An Analysis. IUP Journal of Brand Management, 9(3), 18-23.

Fan, Y. (2005). Ethical branding and corporate reputation. Corporate communications: An international journal.8(1), 25-33.

George, B., Li, C., \& Hou, Y. (2020). Human Resource Management Strategies in the Chinese Multinational Corporations: Ideology, Institutions, and Culture. Ecoforum Journal, 9(3), 17-25.

George, B. \& Bucatariu, L. (2020). The 'coming of age' of telehealth, with NCOVID-19 in context. Basel: MDPI AG.

Haghighi, M., Gharleghi, E., \& Nikbakht, F. (2012). A survey of the factors affecting international exhibition center branding (Case study: Iran Fair). Iranian Business Management, 4(13), 71-90.

Hall, C. Michael, Daniel Scott, and Stefan Gössling. "Pandemics, transformations and tourism: Be careful what you wish for." Tourism Geographies (2020), 22(3), 1-22.

Henthorne, T. L., George, B. P., \& Miller, M. M. (2016). Unique selling propositions and destination branding: A longitudinal perspective on the Caribbean tourism in transition. Turizam: međunarodni znanstveno-stručni časopis, 64(3), 261-275.

Henthorne, T. L., Williams, A. J., \& George, B. P. (2018). Cross-cultural consumer complaining behavior in service industries: A three-nation study across the African diaspora. Journal of Marketing Theory and Practice, 26(4), 431-446.

Holt, D. B. (2002). Why do brands cause trouble? A dialectical theory of consumer culture and branding. Journal of consumer research, 29(1), 70-90.

Holt, D. B., \& Holt, D. B. (2004). How brands become icons: The principles of cultural branding. Harvard Business Press.

Jalilvand, M. R., Esfahani, S. S., \& Samiei, N. (2010). Destination branding and tourists' attitudes (the case of Isfahan as a tourism destination in Iran). International Journal of Marketing Studies, 2(2), 235. 
Javier, A. G., Valdez, J. C. T., \& Mendoza, V. V. S. (2020). Análisis cronológico del proceso de formación de la imagen turística a través de modelos teóricos. Revista Anais Brasileiros de Estudos Turísticos-ABET (ISSN 2238-2925), 10 (1, 2 e 3$)$.

Keller, K. L., \& Lehmann, D. R. (2006). Brands and branding: Research findings and future priorities. Marketing science, 25(6), 740-759.

Khodadadi, M. (2019). Challenges of Branding Iran: Perspectives of Iranian Tourism Suppliers. Tourism Planning \& Development, 16(1), 112-117.

Kolbl, Ž., Arslanagic-Kalajdzic, M., \& Diamantopoulos, A. (2019). Stereotyping global brands: Is warmth more important than competence?. Journal of Business Research, 104, 614-621.

Korstanje, M. E. (2020). El Turismo en un Mundo Incierto: desafios para el siglo XXI en un contexto post COVID19. Revista Anais Brasileiros de Estudos Turísticos-ABET (ISSN 2238-2925), 10(1, 2 e 3), 1-11.

Korstanje, M. E., \& George, B. (2012). Global warming and tourism: chronicles of apocalypse?. Worldwide Hospitality and Tourism Themes, 4(4), 332-355.

Lin, L. Y., \& Chen, C. S. (2006). The influence of the countryof-origin image, product knowledge and product involvement on consumer purchase decisions: an empirical study of insurance and catering services in Taiwan. Journal of Consumer Marketing, 23(5), 248265. http://dx.doi.org/10.1108/07363760610681655
Magier-Łakomy, E., \& Rozkwitalska, M. (2013). Country-of-origin effect on manager's competence evaluations. Journal of Intercultural Management, 5(4), 5-21.

Okonkwo, U. (2016). Luxury fashion branding: trends, tactics, techniques. Springer.

Mirzaee, S., \& George, B. (2016). Brand archetypes: an experiment with the 'demeter'. Journal of Applied Economics and Business Research, 6(2), 93-105.

Papadopoulos, N., \& Heslop, L. (2002). Country equity and country branding: Problems and prospects. Journal of brand management, 9(4), 294-314.

Parkinson, A. (2009). The rationale for developing global competence. Online Journal for Global Engineering Education, 4(2), 2-12.

Purnell, L. (2002). The Purnell model for cultural competence. Journal of transcultural nursing, 13(3), 193-196.

Schroeder, J. E. (2009). The cultural codes of branding. Marketing Theory, 9(1), 123-126.

Shahin, A., Kazemi, A., \& Mahyari, H. K. (2012). How consumer's perception of country of origin affects brand equity: A case study in Iran. Middle-East Journal of Scientific Research, 12(6), 878-885.

Tantawy, R. Y., \& George, B. P. (2016). Cultures within national cultures: international marketing within the domestic marketing environment. Economic Review: Journal of Economics and Business, 14(1), 26-34.

Processo Editorial / Editorial Process / Proceso Editorial

Editor Chefe / Editor-in-chief / Editor Jefe: PhD Thiago D. Pimentel (UFJF).

Editores Convidados / Guest Editors / Editores Invitados: PhD Subhash K. B. Pillai (Goa University), PhD Sharad K. Kulshreshtha (North-Eastern Hill University, India) \& PhD Maximiliano Korstanje (Palermo University, Argentina).

Recebido/Received: 26.08.2020; Revisado/Revised: 10.10.2020; Aprovado/Approved: 28.01. 2020; Publicado/Published: 08.02.2021. Seção revisada às cegas por pares / Double-blind peer review section / Sessión revisada por pares ciegos. 